Огляди літератури, оригінальні дослідження, погляд на проблему, випадок з практики, короткі повідомлення УДК 612.015.11/.3-02:616-002.78-06:616.36-003.826

DOI 10.11603/1811-2471.2020.v.i1.11067

\title{
ЗМІНИ ЛІПІДНОГО ТА ВУГЛЕВОДНОГО ОБМІНУ В ПАЦІЄНТІВ 3 ПОДАГРОЮ ТА НЕАЛКОГОЛЬНИМ СТЕАТОГЕПАТИТОМ
}

\author{
๑С. М. Андрейчин, У. О. Мудра \\ Тернопільський національний медичний університет імені І. Я Горбачевського МОЗ України
}

РЕзЮМЕ. Патологія суглобового апарату належить до числа частих і поширених хвороб у популяції. Найчастіше серед так званих сольових артропатій виявляють подагру, на клінічний перебіг якої значно впливає коморбідна патологія. Поєднання подагри і неалкогольного стеатогепатиту $\epsilon$ актуальним питанням сьогодення, оскільки обидва захворювання є мультисистемними, з метаболічними та серцево-судинними розладами.

Мета - виявити зміни ліпідного та вуглеводного обміну і оцінити клінічні прояви захворювання в пацієнтів із подагрою в поєднанні з неалкогольним стеатогепатитом.

Матеріал і методи. В дослідженні взяли участь 123 хворих на подагру в період загострення, 3 них 118 (95,9 \%) чоловіків і 5 (4,1 \%) жінок. Хворим проводили загальноклінічне обстеження (збір скарг, анамнезу, вимірювання зросту та маси тіла) та біохімічні тести (визначали функціональні проби печінки, показники ліпідного спектра, вуглеводного обміну, також рівень сечової кислоти (СК) у сироватці крові як маркер порушення пуринового обміну).

Усіх обстежених було поділено на дві групи. До групи І увійшло 65 хворих на подагру без ураження печінки, до групи II - 58 осіб із супутнім НАСГ. Групу порівняння склали 30 практично здорових осіб (П3О).

Встановлено, що розвиток НАСГ у хворих на подагру асоціюється з більшими порушеннями показників функціонального стану печінки (підвищення вмісту СК, активності АлАТ, АсАТ, глікемії, загального білірубіну, зниження рівня загального білка), супроводжується суттєвою дис- та гіперліпідемією (зростання у крові ЗХС, проатерогенних ЛПНЩ, зниження протиатерогенних ЛПВЩ).

Висновок. Наявність НАСГ, як супутнього захворювання у пацієнтів з подагрою, погіршує їх загальний стан і якість життя. Встановлено глибші ліпідні порушення крові при поєднаному перебігу подагри і НАСГ, що погіршує перебіг основного захворювання і підвищує ризик кардіоваскулярних подій.

КЛючОВІ СлОВА: подагра; неалкогольний стеатогепатит; ліпідний обмін; вуглеводний обмін.

Вступ. До числа частих і поширених хвороб у популяції належить патологія суглобового апарату. Значну частку займають так звані сольові артропатії, серед яких найчастіше виявляють подагру хронічне прогресуюче захворювання, пов'язане $з$ порушенням обміну сечової кислоти (СК), яке клінічно проявляється рецидивним артритом, утворенням тофусів та ураженням внутрішніх органів [1]. В останні роки дослідники звертають особливу увагу на багатогранність клінічних проявів подагри, що не обмежується лише ураженням опорнорухового апарату і нирок. Значна частина хворих має ожиріння, порушення ліпідного і вуглеводного обміну, артеріальну гіпертензію, які $\epsilon$ складовими частинами метаболічного синдрому [2-4].

Печінковим проявом метаболічного синдрому $\epsilon$ неалкогольна жирова хвороба печінки, яка включає широкий спектр станів - від неалкогольного стеатозу печінки до неалкогольного стеатогепатиту (НАСГ) і цирозу печінки.

На сьогодні у світі встановлена висока захворюваність на НАСГ, причому існує тенденція до збільшення частоти виникнення вказаної хронічної патології печінки серед населення, розвитку тяжких ускладнень при прогресуванні хвороби, що $\epsilon$ актуальною проблемою сучасної медицини $[5,6]$. Згідно з епідеміологічними даними, зрос- тання НАСГ відбувається на тлі збільшення частоти метаболічного синдрому, ЦД 2-го типу, ожиріння [7]. Гіперурикемія $\epsilon$ важливим фактором ризику розвитку та прогресування неалкогольної жирової хвороби печінки $[8,9]$.

Поєднання НАСГ і подагри $є$ актуальним питанням сьогодення, оскільки обидва захворювання $\epsilon$ мультисистемними, з високим рівнем коморбідності з метаболічними та серцево-судинними розладами, зумовлені генетичною схильністю, факторами навколишнього середовища $[10,11]$. Тому при подагрі важливо досліджувати показники не лише пуринового обміну, а й ліпідного та вуглеводного.

Мета - виявити зміни ліпідного та вуглеводного обміну і оцінити клінічні прояви захворювання в пацієнтів із подагрою в поєднанні з неалкогольним стеатогепатитом.

Матеріал і методи дослідження. У дослідженні взяли участь 123 хворих на подагру в період загострення, з них 118 (95,9\%) чоловіків і $5(4,1 \%)$ жінок. Середній вік склав $(57,73 \pm 1,01)$ року. Діагноз подагри встановлено на основі наказу МО3 України № 676 від 12.10.2006 р. НАСГ діагностували згідно з критеріями «Уніфікованого клінічного протоколу первинної, вторинної (спеціалізованої) медичної допомоги «Неалкогольний стеато- 
Огляди літератури, оригінальні дослідження, погляд на проблему, випадок з практики, короткі повідомлення гепатит» (Наказ МОЗ України від 06.11.2014 р. № 826 ).

У дослідження не включали осіб, які щоденно вживають алкоголь понад 40 мл етанолу на тиждень для чоловіків і 20 мл - для жінок, або в анамнезі, чи на момент огляду мають хронічні гепатити В і С, аутоімунний і медикаментозний гепатити. Також не включали пацієнтів, які протягом останніх 6 місяців використовували препарати з гепатотоксичною дією, мали онкологічні та інфекційні захворювання, алкогольне ураження печінки (верифікований діагноз алкогольного захворювання печінки).

Хворим проводили загальноклінічне обстеження (збір скарг, анамнезу, вимірювання зросту та маси тіла) та біохімічні тести.

IMT розраховували за формулою Кетле: IMT = вага (кг) / зріст $\left(\mathrm{M}^{2}\right)$.

Визначали функціональні проби печінки (АлАТ, АсАТ, білірубін, загальний білок, ліпідний спектр крові). Вміст глюкози в крові встановлювали для діагностики порушень вуглеводного обміну. Також досліджували рівень СК у сироватці крові як маркер порушення пуринового обміну.

Показники ліпідного спектра визначали за допомогою набору реагентів згідно зі стандартними методиками. У всіх пацієнтів вивчали загальний холестерин (ЗХC), холестерин ліпопротеїдів високої щільності (ХС ЛПВЩ), холестерин ліпопротеїдів низької щільності (ХС ЛПНЩ), тригліцериди (ТГ). Вміст холестерину ліпопротеїдів дуже низької щільності (ХС лПДНЩ) розраховували за співвідношенням ТГ / 2,22, коефіцієнт атерогенності (KA) - за формулою: КА = (3ХС - лПВЩ) / лПВЩ.

У ході дослідження всіх хворих поділили на дві групи. До групи І увійшли 65 хворих на подагру без ураження печінки, до групи II - 58 осіб із супутнім НАСГ. Групу порівняння склали 30 практично здорових осіб (ПЗО).

Статистичну обробку отриманих даних проводили з використанням пакета програм Statistica 10.0 ("StatSoft", США) і пакета статистичних функцій Microsoft Office Excel 2016 (Microsoft Corp., США). Оцінку достовірності відмінностей між групами проводили із застосуванням непараметричного методу за U-критерієм Уілкоксона (МаннаУїтні). Відмінності вважали статистично значимими при р<0,05. При проведенні кореляційного аналізу застосовували метод параметричної кореляції з визначенням лінійного коефіцієнта кореляції Пірсона (г) з подальшою перевіркою достовірності результату за допомогою критерію Стьюдента.

Результати й обговорення. Основною скаргою усіх пацієнтів, яка змусила їх звернутися за медичною допомогою, був біль як один із проявів

суглобового синдрому. Припухлість ураженого суглоба була у 53 (81,5 \%) хворих групи I і 54 (93,1 \%) групи II, з почервонінням шкіри у 45 (69,2 \%) і 56 (97\%) відповідно, підвищення локальної температури у 50 (77 \%) й 54 (93,1 \%) осіб, підвищення температури тіла до субфебрильних цифр виявлено у 11 (17\%) і 13 (22,4 \%) обстежених.

Варто зазначити, що у пацієнтів з подагрою і НАСГ також спостерігався астеноневротичний синдром (рис. 1), основними проявами якого були загальна слабкість, швидка втомлюваність, зниження працездатності, дратівливість. Вказані симптоми переважали у хворих на подагру із супутнім НАСГ, що можна пов'язати з порушенням дезінтоксикаційної функції печінки і вираженішою ендогенною інтоксикацією.

Біль, здебільшого у правій підреберній ділянці, мав тупий, ниючий характер, посилювався після вживання їжі, також обстежених турбувало відчуття важкості та дискомфорту у верхній половині живота та епігастрії. Ці скарги виявлено в пацієнтів обох груп: у 13,8 \% хворих з подагрою без ураження печінки і у 87,9 \% - із супутнім НАСГ.

Диспепсичні явища траплялися дещо рідше. Пацієнти обох груп скаржились на періодичну нудоту, гіркоту в роті, зниження апетиту, метеоризм, нестійкі випорожнення (чергування запорів із проносами). Цей симптомокомплекс розвивався частіше у хворих із супутньою патологією печінки, що може бути обумовлено негативним впливом на печінку і органи травлення нестероїдних протизапальних препаратів, анальгетиків (рис. 1).

3 метою виявлення ожиріння, як складової частини метаболічного синдрому, усім пацієнтам вимірювали IMT. Середнє значення IMT у пацієнтів з подагрою без ураження печінки становило $(29,13 \pm 0,43)$ кг/м², у хворих із супутнім НАСГ $(33,37 \pm 0,50)$ кг/м². Нормальну масу тіла мали лише 5 (7,7 \%) хворих на подагру, надмірну масу тіла і ожиріння І ступеня мали 31 (47,7 \%) і 27 (41,5 \%) осіб, ожиріння II ступеня - 2 (3,1\%) обстежуваних I групи. У 12 (20,7 \%) пацієнтів із супутнім НАСГ (II група) виявлено надмірну масу тіла, а також ожиріння різного ступеня, зокрема I ступеня - у 26 (44,8\%), II - у 17 (29,3\%), III - у 3 (5,2\%) хворих.

Аналіз показників функціонального стану печінки показав збільшення $(p<0,05)$ в сироватці крові концентрації загального білірубіну, білка, активності АлАТ, АсАТ, а також підвищення рівня глюкози, СК у пацієнтів з подагрою і супутнім НАСГ (табл. 1).

Було виявлено зростання $(p<0,05)$ рівня усіх досліджуваних показників при ураженні печінки у хворих групи II, порівняно з групою І. Встановлено 
Огляди літератури, оригінальні дослідження, погляд на проблему, випадок з практики, короткі повідомлення

Біль у правому підребер'ї

Тяжкість і дискомфорт у правому підребер'ї

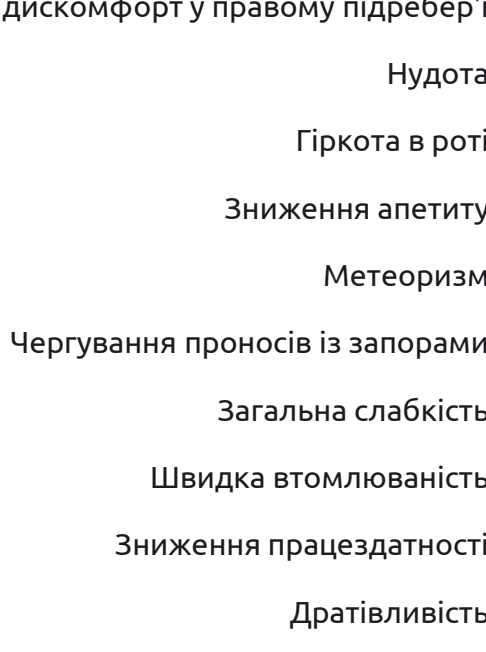

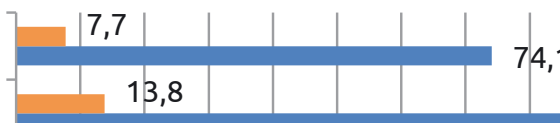

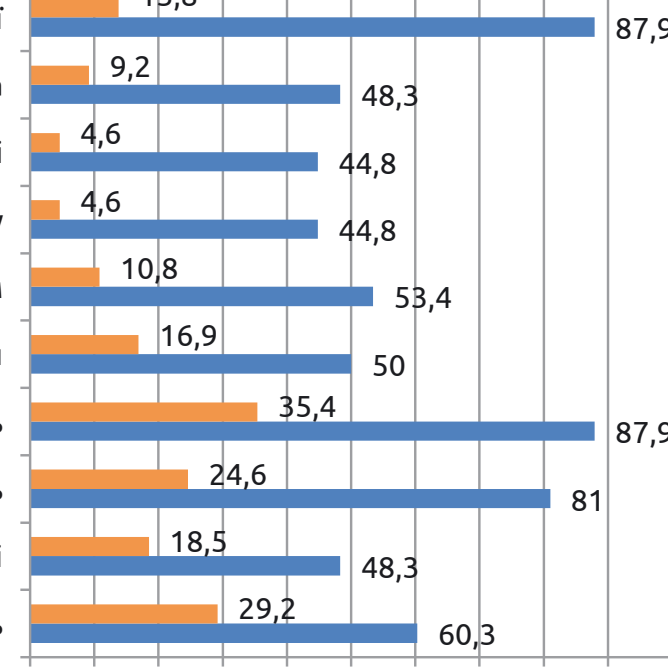

$\begin{array}{lllllllllll}0 & 10 & 20 & 30 & 40 & 50 & 60 & 70 & 80 & 90 & 100\end{array}$
- І група

- II група

Рис. 1. Частота скарг у пацієнтів з подагрою та з подагрою і НАСг (\%).

Таблиця 1. Показники функціонального стану печінки у хворих на подагру

\begin{tabular}{|c|c|c|}
\hline Показник & $\begin{array}{c}\text { Група I } \\
(\mathrm{n}=65)\end{array}$ & $\begin{array}{c}\text { Група II } \\
(n=58)\end{array}$ \\
\hline СК, мКмоль/л & $459,72 \pm 11,44$ & $621,57 \pm 13,4^{*}$ \\
\hline Глюкоза, ммоль/л & $5,77 \pm 0,16$ & $6,54 \pm 0,18 *$ \\
\hline АлАТ, ОД/л & $28,09 \pm 1,40$ & $47,80 \pm 1,18 *$ \\
\hline АсАТ, ОД/л & $27,52 \pm 1,37$ & $41,27 \pm 0,71 *$ \\
\hline Загальний білірубін, мкмоль/л & $20,71 \pm 0,53$ & $27,79 \pm 0,72 *$ \\
\hline Загальний білок, г/л & $72,44 \pm 1,15$ & $61,57 \pm 0,72^{*}$ \\
\hline
\end{tabular}

Примітка. * - вірогідність різниці показників між I та II групами хворих $(p<0,05)$.

підвищення вмісту СК в 1,35 раза, активності АлАТ в 1,70 раза, АсАТ в 1,50 раза. Також зріс рівень загального білірубіну в 1,34 раза й дещо знизився рівень загального білка - в 1,18 раза. Суттєво вищий рівень глікемії був серед пацієнтів групи II.

Дослідження ліпідного спектра крові у пацієнтів з подагрою та супутнім НАСГ виявило суттєві зміни ліпідограми (табл. 2).
Вміст у крові 3 XС зріс у 1,15 i 1,38 раза $(p<0,05)$, порівняно з ПЗО, у хворих I і II груп, також збільшилася концентрація ТГ, суттєвіше у пацієнтів із супутнім НАСГ $(p<0,001)$. Концентрація у крові проатерогенних фракцій ліпопротеїдів - лПНЩ, лПДНЩ у пацієнтів обох груп була вірогідно вищою, порівняно з контролем: у хворих I групи в 1,14 і 1,39 раза, II групи - 1,48 раза й 2,83 раза

Таблиця 2. Показники ліпідного обміну у хворих на подагру

\begin{tabular}{|l|c|c|c|c|}
\hline \multicolumn{1}{|c|}{ Показник } & $\begin{array}{c}\text { Контрольна група } \\
(\mathrm{n}=30)\end{array}$ & $\begin{array}{c}\text { Група I } \\
(\mathrm{n}=65)\end{array}$ & $\begin{array}{c}\text { Група II } \\
(\mathrm{n}=58)\end{array}$ & $\mathrm{p}$ \\
\hline 3ХС, ммоль/л & $4,57 \pm 0,15$ & $5,25 \pm 0,16^{*}$ & $6,30 \pm 0,18^{*}$ & $\mathrm{p}<0,05$ \\
\hline ТГ, ммоль/л & $1,32 \pm 0,09$ & $1,83 \pm 0,11^{*}$ & $3,70 \pm 0,12^{*}$ & $\mathrm{p}<0,05$ \\
\hline лПВЩ, ммоль/л & $1,49 \pm 0,06$ & $1,23 \pm 0,04^{*}$ & $0,98 \pm 0,05^{*}$ & $\mathrm{p}<0,05$ \\
\hline лПНЩ, ммоль/л & $3,06 \pm 0,12$ & $3,50 \pm 0,12^{*}$ & $4,53 \pm 0,20^{*}$ & $\mathrm{p}<0,05$ \\
\hline лПДНЩ, ммоль/л & $0,59 \pm 0,04$ & $0,82 \pm 0,05^{*}$ & $1,67 \pm 0,06^{*}$ & $\mathrm{p}<0,05$ \\
\hline КА & $2,26 \pm 0,19$ & $3,85 \pm 0,35^{*}$ & $6,87 \pm 0,60^{*}$ & $\mathrm{p}<0,05$ \\
\hline
\end{tabular}

Примітка. p - вірогідність різниці показників між I та II групами хворих (p<0,05); * - вірогідність різниці показників стосовно контрольної групи $(p<0,05-0,001)$. 
Огляди літератури, оригінальні дослідження, погляд на проблему, випадок з практики, короткі повідомлення $(p<0,05)$. Водночас у крові знизилась концентрація протиатерогенних ліпопротеїдів - лпвЩ: у пацієнтів з подагрою без ураження печінки в 1,21 раза, при супутньому НАСГ - в 1,52 раза $(p<0,05)$. Виявлено зростання КА серед хворих І групи в 1,70 раза, у 3,04 раза в осіб з патологією печінки $(p<0,05)$.

Аналіз отриманих даних показав наявність кореляційних зв'язків різної сили між досліджуваними показниками у пацієнтів з подагрою без ураження печінки та із супутнім НАСГ, що свідчить про вагомий взаємозалежний вплив. Встановлено, що при наявності НАСГ поглиблюються дисліпідемічні порушення, що підтверджено позитивними сильними та середніми кореляційними зв'язками між рівнем 3 ХС ЛпНЩ $(r=0,8611, p<0,001), K A(r=0,6864$, $p<0,001)$, лПНЩ і KA $(r=0,6810, p<0,001)$ та негативним середнім кореляційним зв'язком між лПВЩ i $3 X С(r=-0,3285, p<0,012)$, ЛПНЩ $(r=-0,4149, p<0,001)$, сильним з КА $(r=-0,8165, p<0,001)$.

Варто зазначити, що у хворих на подагру із супутнім НАСГ показники ліпідного та вуглеводного обміну були достовірно вищими, порівняно з пацієнтами без ураження печінки. Такі зміни свідчать про наявність істотних факторів ризику прогресування атеросклерозу в цих хворих. НАСГ погіршує перебіг основного захворювання і підвищує небезпеку негативних впливів на серцево-судинну систему [12].

Поєднання подагри з НАСГ, надмірною масою тіла і ожирінням $\epsilon$ актуальною проблемою сього-

дення. За даними дослідників, метаболічні порушення ліпідів, вуглеводів і підвищення рівня СК асоціюється з розвитком НАСГ і його прогресуванням. Також підтверджено прямий зв'язок між рівнем СК і вмістом печінкових ферментів у сироватці крові $[13,14]$.

Висновки. 1. Наявність НАСГ, як супутнього захворювання у пацієнтів з подагрою, погіршує їх загальний стан і якість життя, на що вказують збільшення частоти розвитку у них астеноневротичного, диспепсичного синдромів, болю і відчуття важкості в правому підребер'ї та епігастрії.

2. Розвиток НАСГ у хворих на подагру асоціюється з більшими порушеннями показників функціонального стану печінки (підвищення вмісту СК, активності АлАТ, АсАТ, глікемії, загального білірубіну, зниження рівня загального білка), супроводжується суттєвою дис- та гіперліпідемією (зростання у крові ЗХС, проатерогенних ЛПНЩ, зниження протиатерогенних ЛПВЩ).

3. При поєднаному перебігу подагри і НАСГ встановлено глибші ліпідні порушення крові, що погіршує перебіг основного захворювання і підвищує ризик кардіоваскулярних подій.

Перспективи подальших досліджень. Пацієнтам з подагрою та супутнім НАСГ слід уважніше ставитися до діагностики і вибору схеми лікування, враховуючи негативний вплив такої комбінації захворювань на клінічні прояви подагри та можливий розвиток кардіоваскулярних подій.

\section{ЛITEPATУРA}

1. Герасименко С. І. Сучасні аспекти консервативного лікування гострого подагричного артриту / С. І. Герасименко, М. В. Полулях, М. С. Дуда [та ін.] // Літопис травматології та ортопедії. - 2013. - № 1-2. C. 204-207.

2. Bardin T. Impact of comorbidities on gout and hyperuricaemia: an update on prevalence and treatment options / T. Bardin, P. Richette //BMCMed. -2017.-No. 15 (1).P. 123. Doi: 10.1186/s12916-017-0890-9.

3. Камбачокова 3. А. Трудности ведения пациентов с подагрой на фоне коморбидных состояний / 3. А. Камбачокова, Р. М. Арамисова // Трудный пациент. - 2018. № 16 (6). - C. 46-52.

4. Immunological aspects of pathogenesis of gout in light of recent scientic discoveries as a key for development of informative biomarkers and innovative therapeutic strategies / D. V. Maltsev, L. V. Natrus, V. Ye. Kondratiuk, I. E. Degtyarova // Biol. Stud. - 2018. - Vol. 12 (3-4). P. 103-116. DOI: 10.30970/sbi.1203.572.

5. Свінціцький А. С. Особливості перебігу подагри на фоні метаболічного синдрому / А. С. Свінціцький,

Н. П. Козак, А. С. Остафійчук // Укр. ревматол. ж. 2011. - № 4. - С. 46.

6. Скляров $€$. Я. Моніторинг порушень функції печінки у пацієнтів з неалкогольною жировою хворобою печінки на тлі метаболічного синдрому / Є. Я. Скляров, Х. Б. Аксентійчук, Н. В. Курляк // Гепатологія. - 2015. № 1. - C. 34-41.

7. Younossi Z. M. Non-alcoholic fatty liver disease - A global public health perspective / Z. M. Younossi // Journal of Hepatology. - 2019. - Vol. 70 (3). - P. 531-544. DOI: 10.1016/j.jhep.2018.10.033.

8. Serum uric acid levels predict incident nonalcoholic fatty liver disease in healthy Korean men / S. Ryu, Y. Chang, S. G. Kim, J. Cho [et al.] // Metabolism. -2011. - Vol. 60 (6).P. 860-866.

9. Association between serum uric acid and nonalcoholic fatty liver disease in the US population / M. H. Shih, M. Lazo, S. H. Liu [et al.] // Journal of the Formosan Medical Association. - 2015. - Vol. 114 (4). - P. 314-320.

10. Даньчак С. В. Дисметаболічні порушення у паці$\epsilon$ нтів із подагрою в поєднанні з неалкогольною жиро- 
Огляди літератури, оригінальні дослідження, погляд на вою хворобою печінки / С. В. Даньчак // Вісник наукових досліджень. - 2015. - № 3. - С. 56-58.

11. Yang Y. Effect of uric acid on mitochondrial function and oxidative stress in hepatocytes / Y. Yang, Y. Zhou, S. Cheng [et al.] // Genet. Mol. Res. -2016. - Vol. 15 (2).

12. Гриценко М.В.Вплив метаболічного синдрому на стан функції нирок у пацієнтів, що тривало хворіють на подагру / М.В.Гриценко // Журнал клінічних та експериментальних медичних досліджень. - 2018. - Т. 6, о практики, короткі повідомлення № 4. - C. 447-452.

13. Association between serum uric acid level and chronic liver disease in the United States / A. Afzali, N. S. Weiss, E. J. Boyko, G. N. Ioannou // Hepatology. 2010. - Vol. 52 (2). - P. 578-589.

14. Association between serum uric acid and nonalcoholic fatty liver disease in the US population / M. H. Shih, M. Lazo, S. H. Liu [et al.] // Journal of the Formosan Medical Association. - 2015. - Vol. 114 (4). - P. 314-320.

\section{REFERENCES}

1. Herasymenko, S.I., Poluliakh, M.V., Duda, M.S. \& Pshenychnyi, T.le. (2013). Suchasni aspekty konservatyvnoho likuvannia hostroho podahrychnoho artrytu [Current aspects of conservative treatment of acute gouty arthritis]. Litopys travmatolohii ta ortopedii - Chronicle of Traumatology and Orthopedics, (1-2), 204-207 [in Ukrainian].

2. Bardin, T., \& Richette, P. (2017). Impact of comorbidities on gout and hyperuricaemia: an update on prevalence and treatment options. BMC medicine, 15 (1), 123. doi:10.1186/s12916-017-0890-9.

3. Kambachokova, Z.A., \& Aramisova, R.M. (2018). Trudnosti vedeniya patsiyentov s podagroy na fone komorbidnykh sostoyaniy [Difficulties in managing patients with gout amid comorbid conditions]. Trudnyy patsiyent Difficult Patient, 16 (6), 46-52 [in Russian].

4. Maltsev, D.V., Natrus, L.V., Kondratiuk, V.Ye., \& Degtyarova, I.E. (2018). Immunological aspects of pathogenesis of gout in light of recent scientic discoveries as a key for development of informative biomarkers and innovative therapeutic strategies. Studia Biologica, 12 (3-4), 103-116. DOI: 10.30970/sbi.1203.572.

5. Svintsitskyi, A.S., Kozak, N.P., \& Ostafiichuk, A.S. (2011). Osoblyvosti perebihu podahry na foni metabolichnoho syndromu [Features of the course of gout on the background of metabolic syndrome]. Ukr. revmatol. zh. Ukrainian Rheumatology Journal, (4), 46 [in Ukrainian].

6. Skliarov, Ye.Ya., Aksentiichuk, Kh.B., \& Kurliak, N.V. (2015). Monitorynh porushen funktsii pechinky u patsiientiv z nealkoholnoiu zhyrovoiu khvoroboiu pechinky na tli metabolichnoho syndromu [Monitoring of liver function disorders in patients with non-alcoholic fatty liver disease on the background of metabolic syndrome]. HepatolohiiaHepatology, (1), 34-41 [in Ukrainian].

7. Younossi, Z.M. (2019). Non-alcoholic fatty liver disease - A global public health perspective. Journal of
Hepatology, 70 (3), 531-544. PMID:30414863 doi: 10.1016/ j.jhep.2018.10.033.

8. Ryu, S., Chang, Y., Kim, S.G., Cho, J., \& Guallar, E. (2011). Serum uric acid levels predict incident nonalcoholic fatty liver disease in healthy Korean men. Metabolism, 60 (6), 860-866.

9. Shih, M.H., Lazo, M., Liu, S.H., Bonekamp, S., Hernaez, R., \& Clark, J.M. (2015). Association between serum uric acid and nonalcoholic fatty liver disease in the US population. Journal of the Formosan Medical Association, $114(4), 314-320$.

10. Danchak, S.V. (2015). Dysmetabolichni porushennia u patsiientiv iz podahroiu v poiednanni z nealkoholnoiu zhyrovoiu khvoroboiu pechinky [Dysmetabolic disorders in patients with gout in combination with non-alcoholic fatty liver disease]. Visnyk naukovykh doslidzhen - Bulletin of Scientific Research, (3), 56-58 [in Ukrainian].

11. Yang, Y., Zhou, Y., Cheng, S., Sun, J. L., Yao, H., \& Ma, L. (2016). Effect of uric acid on mitochondrial function and oxidative stress in hepatocytes. Genet. Mol. Res., 15 (2).

12. Hrytsenko, M.V. (2018). Vplyv metabolichnoho syndromu na stan funktsii nyrok u patsiientiv, shcho tryvalo khvoriiut na podahru [Influence of metabolic syndrome on kidney function in patients with chronic gout]. Zhurnal klinichnykh ta eksperymentalnykh medychnykh doslidzhen - Journal of Clinical and Experimental Medical Research, 6 (4), 447-452 [in Ukrainian].

13. Afzali, A., Weiss, N.S., Boyko, E.J., \& Ioannou, G.N. (2010). Association between serum uric acid level and chronic liver disease in the United States. Hepatolo$g y, 52(2), 578-589$.

14. Shih, M.H., Lazo, M., Liu, S.H., Bonekamp, S., Hernaez, R., \& Clark, J.M. (2015). Association between serum uric acid and nonalcoholic fatty liver disease in the US population. Journal of the Formosan Medical Association, 114 (4), 314-320. 


\title{
Огляди літератури, оригінальні дослідження, погляд на проблему, випадок з практики, короткі повідомлення ИЗМЕНЕНИЯ ЛИПИДНОГО И УГЛЕВОДНОГО ОБМЕНА У ПАЦИЕНТОВ С ПОДАГРОЙ И НЕАЛКОГОЛЬНЫМ СТЕАТОГЕПАТИТОМ
}

\author{
○С. М. Андрейчин, У. О. Мудра
}

Тернопольский национальный медицинский університет имени И. Я. Горбачевского МОз Украины

РЕЗЮМЕ. Патология суставного аппарата относится к числу частых и распространенных болезней в популяции. Чаще всего среди так называемых солевых артропатий выявляют подагру, на клиническое течение которой значительно влияет коморбидная патология. Сочетание подагры и неалкогольного стеатогепатита (НАСГ) сегодня является актуальным вопросом, поскольку оба заболевания являются мультисистемными, с метаболическими и сердечно-сосудистыми расстройствами.

Цель - выявить изменения липидного и углеводного обмена и оценить клинические проявления заболевания у пациентов с подагрой в сочетании с неалкогольным стеатогепатитом.

Материал и методы. В исследовании приняли участие 123 больных подагрой в период обострения, из них 118 (95,9 \%) мужчин и 5 (4,1 \%) женщин. Больным проводили общеклиническое обследование (сбор жалоб, анамнеза, измерения роста и массы тела) и биохимические тесты (определяли функциональные пробы печени, показатели липидного спектра, углеводного обмена, также уровень мочевой кислоты (МК) в сыворотке крови, как маркер нарушения пуринового обмена).

Все пациенты были поделены на две группы. В группу I вошло 65 больных подагрой без поражения печени, в группу II - 58 человек с сопутствующим НАСГ. Группу сравнения составили 30 практически здоровых лиц.

Установлено, что развитие НАСГ у больных подагрой ассоциируется с большими нарушениями показателей функционального состояния печени (повышение содержания МК, активности АлАТ, АсАТ, гликемии, общего билирубина, снижение уровня общего белка), сопровождается существенными дис-и гиперлипидемией (рост в крови ОХС, проатерогенных ЛПнП, снижение противоатерогенных ЛПВП).

Вывод. Наличие НАСГ, как сопутствующего заболевания у пациентов с подагрой, ухудшает их общее состояние и качество жизни. Установлены более глубокие липидные нарушения крови при совместном течении подагры и НАСГ, что ухудшает течение основного заболевания и повышает риск кардиоваскулярных событий.

КЛючЕВЫЕ СЛОВА: подагра; неалкогольный стеатогепатит; липидный обмен; углеводный обмен.

\section{CHANGES IN LIPID AND CARBOHYDRATE METABOLISM IN PATIENTS WITH GOUT AND NON-ALCOHOLIC STEATOHEPATITIS}

\section{@S. M. Andreychyn, U. O. Mudra \\ I. Horbachevsky Ternopil National Medical University}

SUMMARY. Pathology of the joint apparatus is one of the frequent and common diseases in the population. Most often, among the so-called saline arthropathies, gout is detected, the clinical course of which is significantly affected by comorbid pathology. The combination of gout and non-alcoholic steatohepatitis is a pressing issue today, as both diseases are multisystemic with metabolic and cardiovascular disorders.

The aim of the study - to detect changes in lipid and carbohydrate metabolism and to evaluate the clinical manifestations of the disease in patients with gout in combination with nonalcoholic steatohepatitis.

Material and Methods. The study involved 123 patients with gout during the exacerbation period, including 118 (95.9\%) men and 5 (4.1\%) women. Patients underwent general clinical examination (complaint collection, medical history, measurements of height and body weight) and biochemical tests (determined liver functional tests, lipid spectrum, carbohydrate metabolism, as well as serum levels of uric acid (UA) as a marker of disruption of purine metabolism).

All surveyed were divided into two groups. Group I included 65 patients with gout without liver damage, group II included 58 people with concomitant NASH. The comparison group consisted of 30 practically healthy persons.

It is established that the development of NASH in patients with gout is associated with major disorders of the functional state of the liver (increase in UA content, activity of ALT, AST, glycemia, total bilirubin, decrease in the level of total protein), accompanied by significant dys- and hyperlipidemia.

Conclusion. The presence of NASH, as a concomitant disease in patients with gout, impairs their overall condition and quality of life. Deeper blood lipid abnormalities were established with the combined course of gout and NASH, which degrade the course of the underlying disease and increases the risk of cardio-vascular events.

KEY WORDS: gout; non-alcoholic steatohepatitis; lipid metabolism; carbohydrate metabolism.

Отримано 11.02.2020 